\title{
Special Considerations for Specimen Collections That May Be Involved in Law Enforcement Cases
}

Chapter 7 of

Section C, Techniques in Disease Surveillance and Investigation

Book 15, Field Manual of Wildlife Diseases

Techniques and Methods 15-C7 



\section{Special Considerations for Specimen Collections That May Be Involved in Law Enforcement Cases}

By Tabitha Viner

Chapter 7 of

Section C, Techniques in Disease Surveillance and Investigation

Book 15, Field Manual of Wildlife Diseases

Edited by J. Christian Franson, Milton Friend, Samantha E.J. Gibbs, and Margaret A. Wild

U.S. Geological Survey, U.S. Fish and Wildlife Service, and National Park Service

Techniques and Methods 15-C7 


\title{
U.S. Department of the Interior SALLY JEWELL, Secretary
}

\section{U.S. Geological Survey Suzette M. Kimball, Acting Director}

\author{
U.S. Geological Survey, Reston, Virginia: 2015
}

For more information on the USGS - the Federal source for science about the Earth, its natural and living resources, natural hazards, and the environment, visit http://www.usgs.gov or call 1-888-ASK-USGS.

For an overview of USGS information products, including maps, imagery, and publications, visit http://www.usgs.gov/pubprod.

To order this and other USGS information products, visit http://store.usgs.gov.

Any use of trade, firm, or product names is for descriptive purposes only and does not imply endorsement by the U.S. Government.

Although this information product, for the most part, is in the public domain, it also may contain copyrighted materials as noted in the text. Permission to reproduce copyrighted items must be secured from the copyright owner.

Suggested citation:

Viner, T.C., 2015, Special considerations for specimen collections that may be involved in law enforcement cases, in Franson, J.C., Friend, M., Gibbs, S.E.J., and Wild, M.A., eds. Field manual of wildlife diseases: U.S. Geological Survey Techniques and Methods, 15-C7, 16 p., http://dx.doi.org/10.3133/tm15c7.

ISSN 2328-7055 (online) 


\section{Contents}

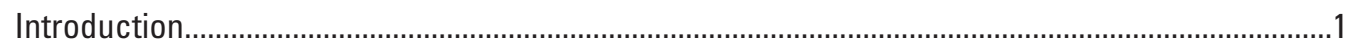

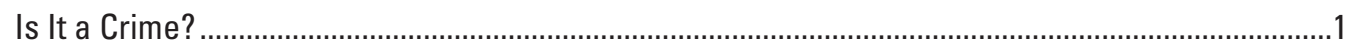

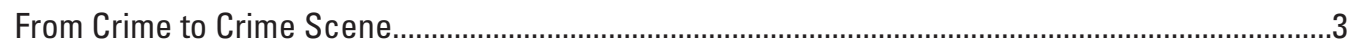

Anatomy of an Investigation ...............................................................................................................

Steps a Law Enforcement Agent May Take to Process a Crime Scene....................................4

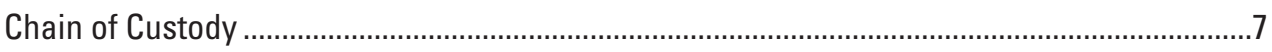

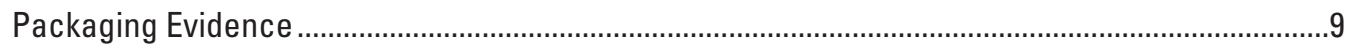

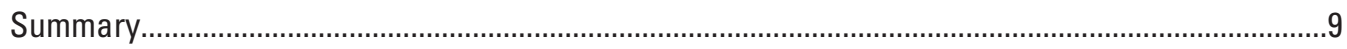

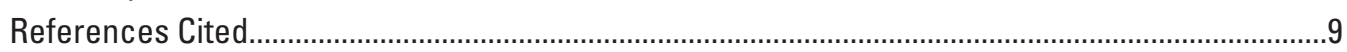

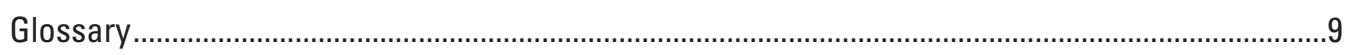

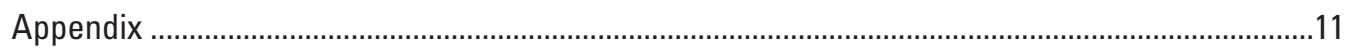

\section{Figures}

1. Photo showing characteristic posture of a bald eagle that died from ingesting carbamate-laced bait. Note that the talons are flexed, the wings are partially spread, and the head is cocked back and to one side.

2. Photo showing aldicarb, a carbamate insecticide, was placed on this domestic sheep carcass to lure and kill "nuisance" wildlife.

3. Schematics showing search patterns commonly used for a single-person walkthrough of a crime scene: $A$, a spiral pattern; $B$, a linear pattern; $C$, a grid pattern .........5

4. Photo showing a long-distance image of a crime scene shows the geographical layout of the scene and items of interest within it, such as the scene boundary and an abandoned car

5. Photo showing the mid-distance image of an evidence item, indicated with a yellow placard, shows its physical distance and position relative to the abandoned car

6. Photo showing close-up image of an evidence item-a shoe print-was taken directly above it. This view eliminates distortion and accurately depicts the architecture of the print

7. This form is an example of a chain of custody record. Whenever an evidence item is passed between people, each party signs and dates the chain of custody to ensure the integrity of the evidence item

\section{Tables}

1. Information to be recorded by the reporting party ....................................................

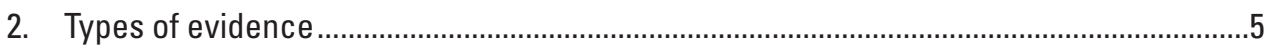

The first use of a word defined in the glossary is shown in bold type (not including headings, words in illustrations, and table column headings). 



\title{
Special Considerations for Specimen Collections That May Be Involved in Law Enforcement Cases
}

\author{
By Tabitha Viner ${ }^{1}$
}

\section{Introduction}

Causes of mortality in wildlife include natural conditions - such as the viral, bacterial, and fungal diseases discussed in other chapters of this manual - and human intervention. Direct human intervention in wildlife deaths may be associated with individual human actions, such as gunshot or poisonings, or with institutions, such as wind farms or mining operations. Mortality that can be directly attributed to humans may be considered a crime based on the animal(s) affected and (or) the agent used.

Wildlife laws were established to protect our nation's wildlife resources and assist in conserving healthy populations of native wildlife. A variety of laws pertain to wildlife, such as the Migratory Bird Treaty Act, which makes it illegal, except as permitted, to capture, kill, or possess a portion or all of any migratory bird, a member of the group that includes the vast majority of wild birds present in the United States. Similar to pathogens that can spread unchecked through a wild population, a person or an institution that illegally kills wildlife may continue this practice indefinitely or until the illegal activities are detected and addressed.

Convicting the perpetrator of a crime, however, requires that certain practices and procedures be followed so that a solid legal case can be constructed. As with any crime, investigation of the event is led by law enforcement personnel who are well-versed in the applicable laws, oversee the collection of evidence, and pursue persons or entities of interest. These individuals are uniquely qualified and trained to maintain the integrity of evidence, evaluate suspects to effectively prosecute the case, and effect the penalties of the law. The investigation of direct crimes against humans may involve teams of 5-10 law enforcement agents and specialists - each with a certain focus such as blood spatter, fingerprints, or ballistics - in processing a crime scene. In contrast, investigations of crimes against wildlife generally involve markedly fewer wildlife law enforcement agents, and in many instances of unlawful wildlife death, only one law enforcement agent is available to process an entire crime scene and work on a case. Thus, the assistance of individuals familiar with the geographical area,

${ }^{1}$ U.S. Fish and Wildlife Service. the endemic animal populations, and the local ecology can be very important for building an effective case.

The aims of this chapter are to 1) help biologists or field personnel recognize the signs that indicate a crime may have been committed, and 2) to give readers a basic understanding of how a wildlife crime scene is processed. This chapter is not intended to give readers the tools to investigate a crime scene alone, but will hopefully make them a valuable asset to law enforcement agents who respond to the scene. An effectively processed case, resulting in prosecution of a suspect, supports the law as a deterrent to future acts that could endanger the conservation of wildlife.

\section{Is It a Crime?}

Unlawful wildlife deaths may occur singly or in groups, depending on the cause. This is the same for naturally occurring wildlife deaths. Dead geese scattered around a pond may have died due to botulinum toxin in the water-which is an organic, environmental event - or poisoned feed. Similarly, a single, thin, dead eagle may have succumbed to aspergillosis or anticoagulant ingestion. Careful assessment of the animal carcass and its surroundings can help in determining whether a crime may have been committed and a law enforcement agent should be notified. Regardless of the etiology of the animal's death, it is prudent to not delay contacting the appropriate individual(s) so that a postmortem exam can be done while tissues are still relatively well preserved.

Signs that may indicate criminal activity:

1. Proximity to manmade structures.Some people see wildlife as a nuisance to be eliminated from their property and will attempt to do so directly by several means, including shooting or poisoning animals around their homes or farms. Industrial institutions may indirectly kill wildlife by creating ponds or catch basins for toxic effluent. Although the people who built the ponds may not be present when the animal comes into contact with the toxic elements, the corporations are still liable for any resulting mortalities. 
2. Position of the body. Birds that are poisoned with organophosphate or carbamate insecticides exhibit a characteristic death posture due to the neurological effects of the poison (fig. 1). Birds often are face down (ventrally recumbent) with partially spread wings. The talons are tightly clenched, often around vegetation or other substrate, and the head may be directed to one side or the other. Because these poisons kill very quickly, occasionally several birds are around a central pile of poison-laced bait.

3. Condition of the body.The condition of the body may provide valuable indicators of criminal activity. Antlers, claws, feathers, or tails may be removed postmortem as trophy pieces. The absence of these body parts may indicate criminal activity rather than scavenging by other animals. Also, singeing of the feathers can indicate that a bird may have contacted a power pole. No level of postmortem decomposition precludes an investigation, and the degree of autolysis may provide valuable information to a law enforcement agent working on a case.

4. Changes in the area. Items may be present near a carcass that normally would not be there. Poison-laced eggs placed in egg cartons or domestic animal carcasses are used to attract wildlife to the toxin (fig. 2). The presence of egg cartons or dead sheep in remote areas should spark suspicion. People who have killed an animal often investigate the carcass prior to leaving the scene. When they investigate, they may leave items such as drink bottles, chewing tobacco, or cigarette butts. They may also leave footprints in soft soil or mud. The presence of these signs in areas not frequented by people may indicate that the death was not natural. In addition, keep in mind things that should be there, but that are absent. For example, branches may be detached to clear a view from a blind, or leaf litter may be removed from an area that once had bait on it.

5. The presence or lack of blood. Blood on the feathers or hair coat of a dead animal is an obvious sign that the animal may have died a traumatic death. Gunshot wounds, blunt force impact, and intraspecific aggression can all result in wounds that bleed. It is important to note, however, that all these traumatic events may cause fatality without apparent external bleeding. Intraspecific aggression between wolves, for example, may result in massive laceration of the neck musculature but only few, small puncture wounds in the skin. This can result in heavy bleeding under the skin, but very little obvious hemorrhage on the outside. Similarly, gunshot wounds in birds may cause marked internal organ damage and very little bleeding from the projectile's entry and exit points.

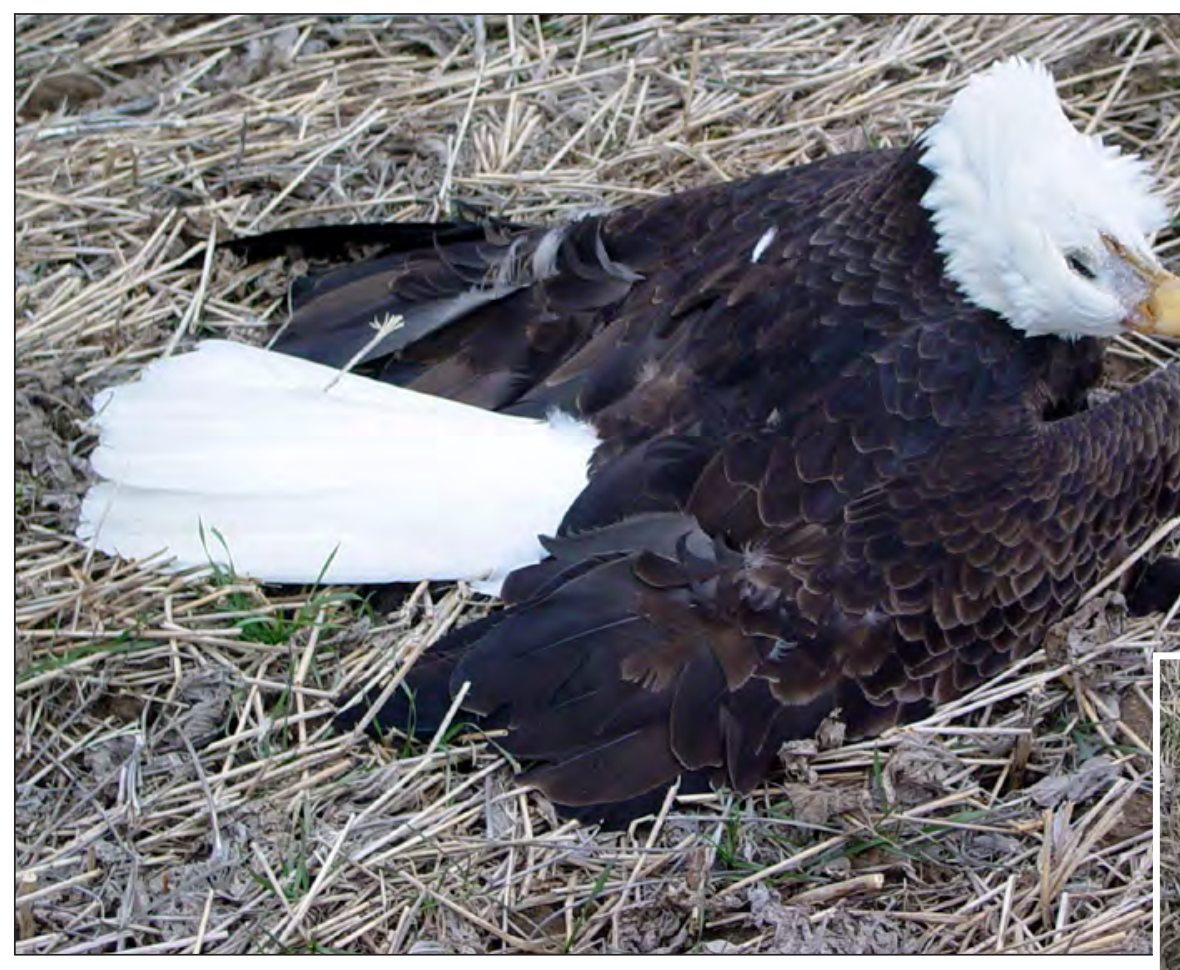

Figure 1. This is a characteristic posture of a bald eagle (Haliaeetus leucocephalus) that died from ingesting carbamate-laced bait. Note that the talons are flexed, the wings are partially spread, and the head is cocked back and to one side. Birds in this position should be considered victims of a crime, and the appropriate law enforcement agent(s) should be notified. (Photo by Richard Stroud)

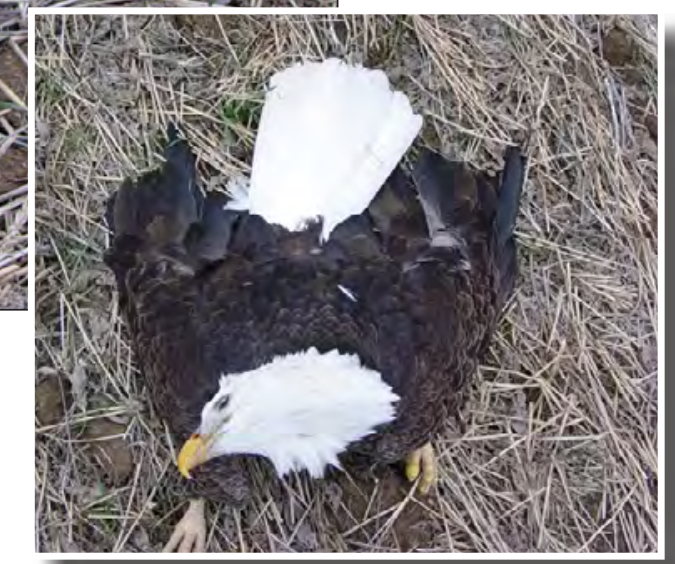




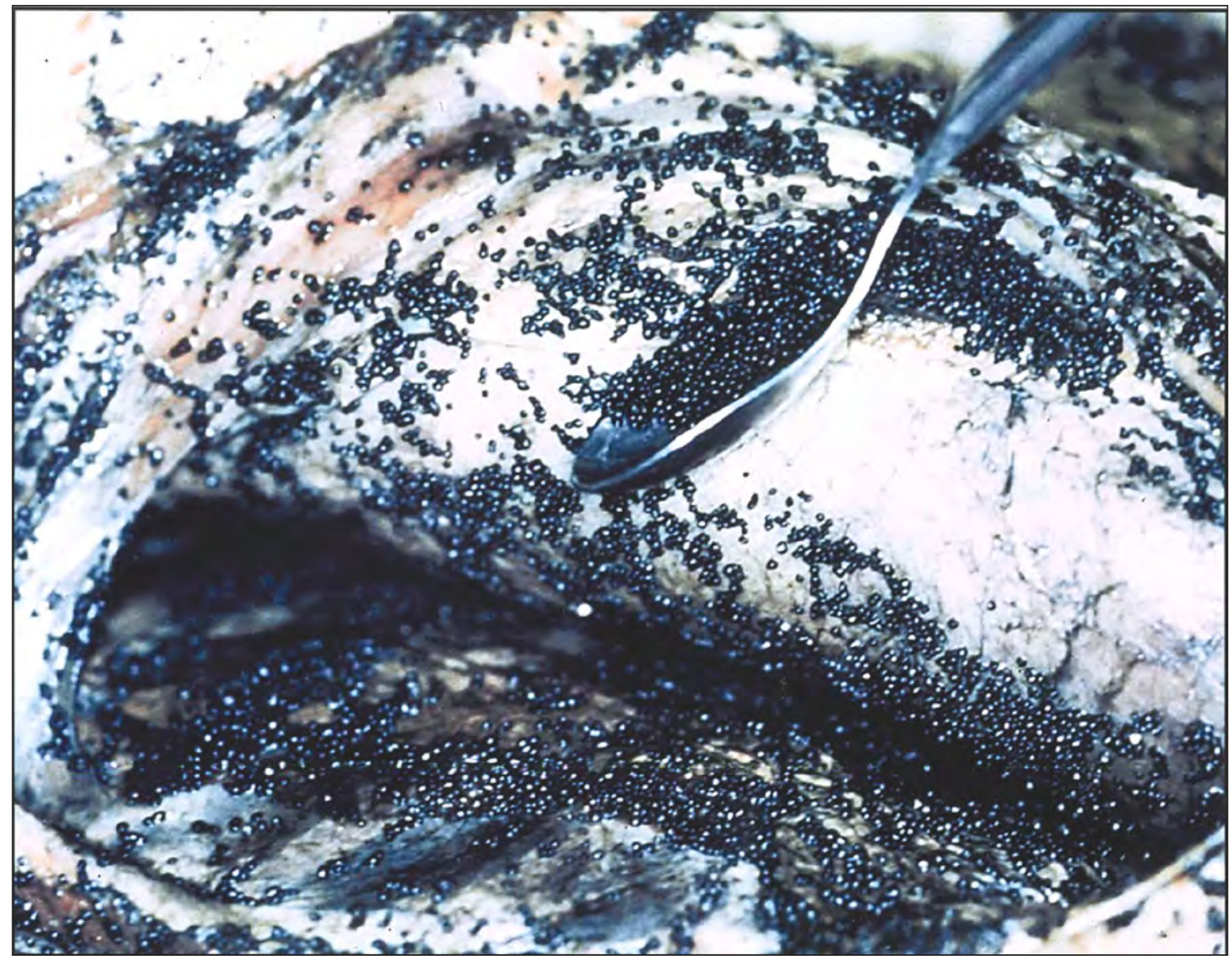

Figure 2. Aldicarb, a carbamate insecticide, was placed on this domestic sheep carcass to lure and kill “nuisance" wildlife. (Photo by Richard Stroud)

\section{From Crime to Crime Scene}

If there is a suspicion that a crime has been committed against wildlife, it is best to contact the appropriate law enforcement office and treat the area in question as a crime scene. Avoid disturbing the ground, carcass, and environment until a law enforcement officer arrives at the scene. Seek agency assistance for consultation of common State and Federal wildlife laws that cover wildlife mortalities. If the animal is a bird or an endangered species, then the incident may be covered under the Migratory Bird Treaty Act and (or) the Endangered Species Act, and the regional U.S. Fish and Wildlife Service Office of Law Enforcement should be contacted. Criminal mortality in other animals, such as outof-season poaching, may be covered under State law. See Appendix 1 for Federal and State law enforcement agency contact information.
The person who discovered the carcass (the "reporting party") may provide invaluable information to the law enforcement agent who responds to the scene. Documentation of the environment and other data can help in the ensuing investigation and may provide evidence that could lead to identification of a suspect. Environmental conditions can change rapidly, and scavengers can be very efficient; thus, these changes can alter the scene or the carcass and may destroy evidence pertinent to the case. Effective documentation of the scene at the time of discovery can help preserve these original data in a virtual manner. Some important pieces of information to be recorded by the reporting party are outlined in table 1. In addition, photographs of the conditions of the scene can also help the law enforcement agent in his or her investigation. Further discussion of photography is outlined below. 
Table 1. Information to be recorded by the reporting party.

- Your name, position, and contact information
- Other individuals with you or in the area
- Date and time the carcass was found
- $\quad$ Last time the area was undisturbed or the animal was known to be alive
- $\quad$ Weather data in the recent past (if known)
- $\quad$ Any alterations in the environment you believe to be significant (foot prints, fresh trash, ballistic evidence)
- Notable nearby, temporary or permanent structures (ponds, cars, hunting hides)
- Condition of the carcass (position, preservation, activity of scavengers)
- Expected impacts and (or) interference with the scene conditions and area (incoming weather, visitors to the
scene, presence of vultures)

\section{Anatomy of an Investigation}

When two items make contact, there is almost always a transfer of some material from one item to another. This material may be fibers from a coat deposited on the feathers of a bird or ballistic residue in the hair of a wolf. This transfer of material may be significant to the forensic investigation of the case. It is important to remember that disturbance of the animal and the potential crime scene should be avoided or at least kept to a minimum. Wildlife law enforcement agents are trained to methodically examine the scene of a crime to gather evidence that will hopefully result in the identification of a suspect and prosecution of the case while avoiding the addition of confounding material (Byrd, 2011). Subtle evidence can be inadvertently destroyed or rendered useless simply because it is not seen and is trampled or discarded. Even if objects appear to be of evidentiary value, they should not be handled, but left in place for the law enforcement agent to collect. Handling of objects may obscure fingerprints, trace evidence, or deoxyribonucleic acid (DNA) that could help in the prosecution of the case. In addition, handling of evidence by non-law enforcement personnel may break the important chain of custody, which will be further discussed below.

The initial documentation of the scene and any photographs taken by the biologist or reporting party are very valuable in the exercise of following a case. The biologist can also assist the law enforcement agent by taking part in one or more aspects of crime scene investigation (CSI). Understanding the steps taken during a CSI exercise can help marry the health and ecological aspects of wildlife conservation used by the biologist with the law enforcement aspects of wildlife conservation used by the officer.

\section{Steps a Law Enforcement Agent May Take to Process a Crime Scene}

1. Establish the crime scene perimeter. Crime scene borders define the area where evidence related to a crime is likely to be found. Borders may be established by using the commonly seen crime scene tape or by identifying natural borders, such as a streambed, rock wall, or tree line. The crime scene borders can also help to prevent unwanted individuals from entering the scene and altering, removing, or adding confounding factors to the investigation.

2. Walk through the area.

Closer examination of the area is done by walking through the scene methodically, using a grid, line, or circular pattern (fig. 3) so that, ideally, all surfaces within the scene are examined. During the walk-through, potential evidence items are identified and marked, but they are left in place for later evaluation of their spatial relationships. Evidence items that may be encountered are listed in table 2. A thorough walk-through examination takes into account the ground within the crime scene, as well as the canopy and vertical surfaces throughout it. Too often, people may search hard for a shell casing on the ground yet overlook the tree stand above their heads.

3. Photodocumentation.

Because alteration of the crime scene is inevitable during an investigation, a well-compiled set of photographs can effectively preserve the condition and composition of the scene for future reference (Merck, 2007). A comprehen- 


\section{A. Spiral search pattern}

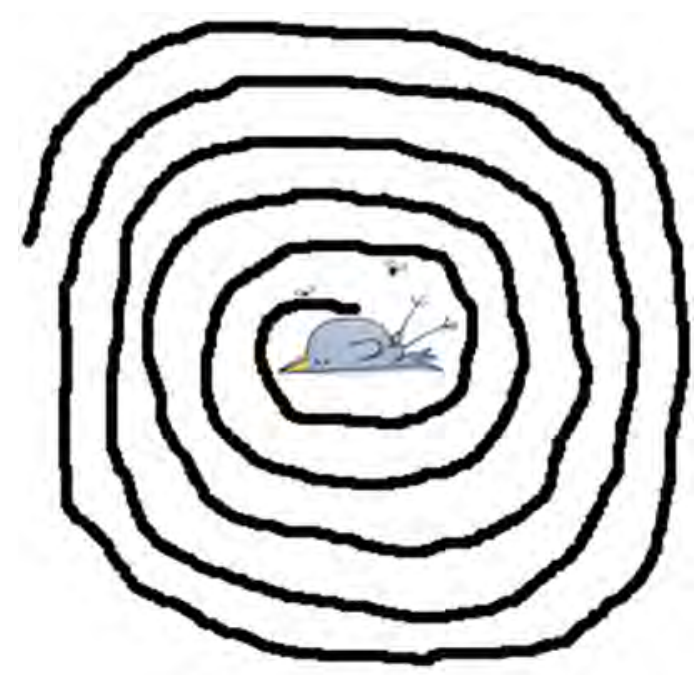

\section{Grid search pattern}

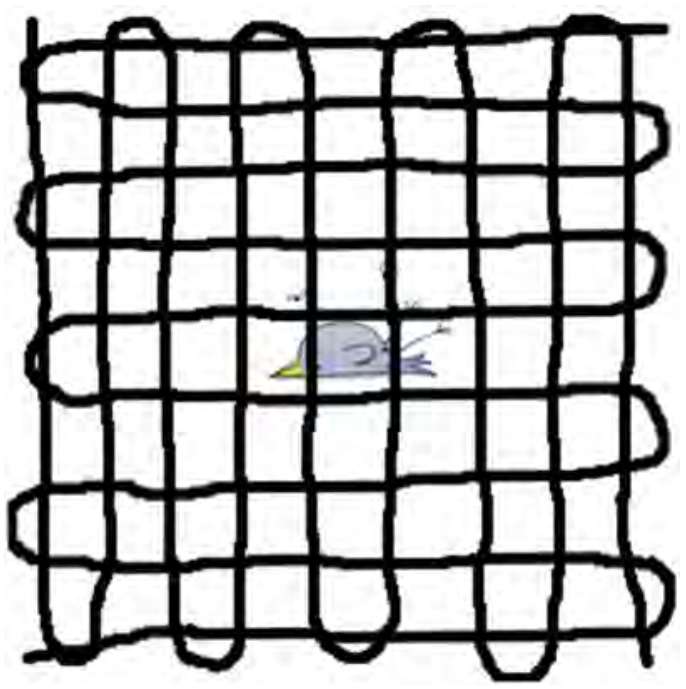

\section{B. Line search pattern}

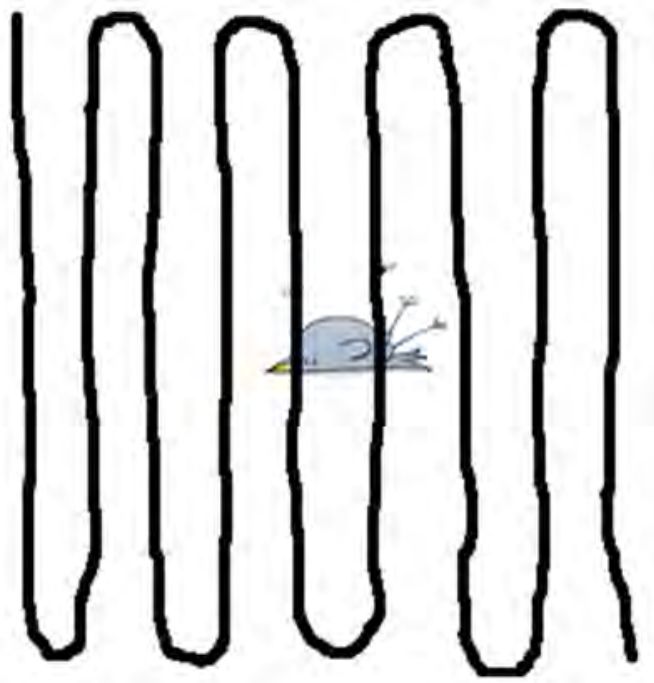

Figure 3. Search patterns commonly used for a singleperson walk-through of a crime scene: $A$, a spiral pattern; $B$, a linear pattern; $C$, a grid pattern. A law enforcement officer may enlist help from a reporting party or biologist in searching a crime scene by using a variation on any of these methods.

Table 2. Types of evidence.

- Carcasses or gut piles

- Blood spatter or pools

- Impression marks such as footprints or tire tracks

- Discarded objects such as soda cans, cigarette butts, or ballistic materials 
sive set of images will utilize orientation, perspective, and scale to convey the state of the crime scene. The orientation of the crime scene and its related evidence can be captured by taking long-, mid-, and close-distance shots of each item of interest (figs. 4-6). Long- and middistance shots allow the viewer to visually place an item within the crime scene, while the close-up details the item. Images should be taken of individual items from a perspective directly above where the object lies, when at all possible. Oblique views may cause distortion or convey the object inaccurately. All evidence items should be photographed with a scale, preferably a ruler, to give the viewer an idea of the item's size. Metadata, including the date, time, and camera settings, is recorded within the image by all digital cameras. Postproduction alterations of the images are also recorded. It is important to remember that altered images - even simple cropping or contrast adjustments - may be inadmissible in a court of law, so only original productions should be stored with the case.

4. Collect the evidence.

Not all evidence that is identified may be collected for analysis. Based on the walk-through and evaluation of the relation of the marked objects to each other, the law enforcement officer will determine whether or not each evidence item may be valuable in the pursuit of a case. The technique of collecting an evidence item is dictated by the tests that are likely to be done on it. For example, items taken for fingerprint analysis are packaged so that absolutely nothing touches the area where the fingerprints may be. Because fingerprints are so fragile, any contact with the item may smudge or obliterate them. Evidence is collected in an appropriate container and sealed with evidence tape, which is initialed and dated by the collector. This "official seal" is tamper evident so that the integrity of the evidence can be assured.

5. Compile the documentation of the scene.

Throughout the course of the investigation of the scene, the law enforcement officer will take notes, make sketches, and photograph the area. Memories can fade and even change, so notes are an excellent way to record everything that was seen and done during the investigation. These notes, sketches, and photographs will eventually be compiled into a report about the case and may be admitted in a court of law during its prosecution. Any notes that the biologist gives to the law enforcement officer may also be included in the report, so handwriting should be clear, information should be thorough and understandable, and extraneous information, such as grocery lists or unrelated personal reminders, should be avoided. Notes taken by the reporting party should be purely objective, stating only facts related to the case. Avoid subjective opinions about the scene or cause of death, because they may cause conflicts during the investigation and potential subsequent legal proceedings.

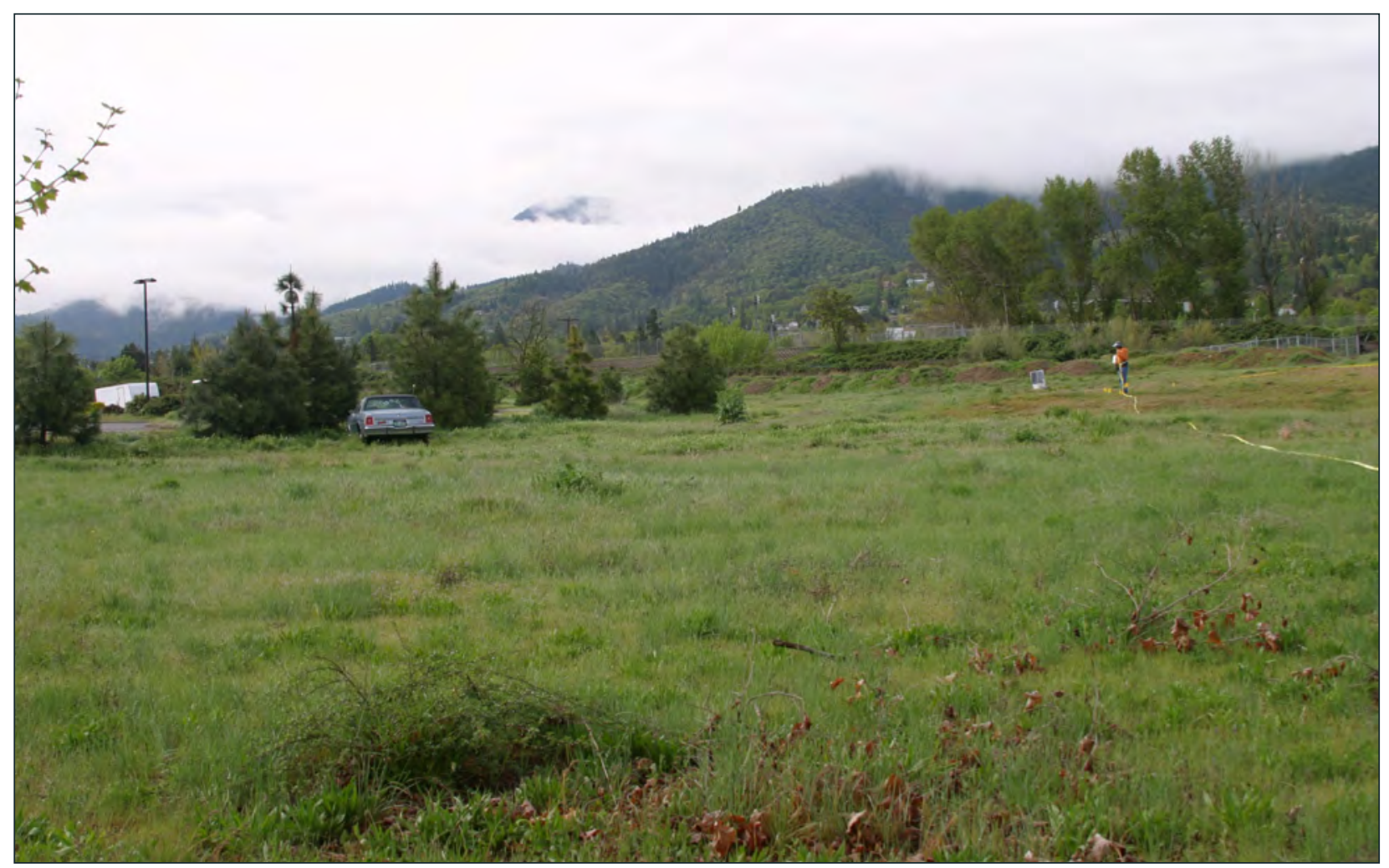

Figure 4. A long-distance image of a crime scene shows the geographical layout of the scene and items of interest within it, such as the scene boundary and an abandoned car. 


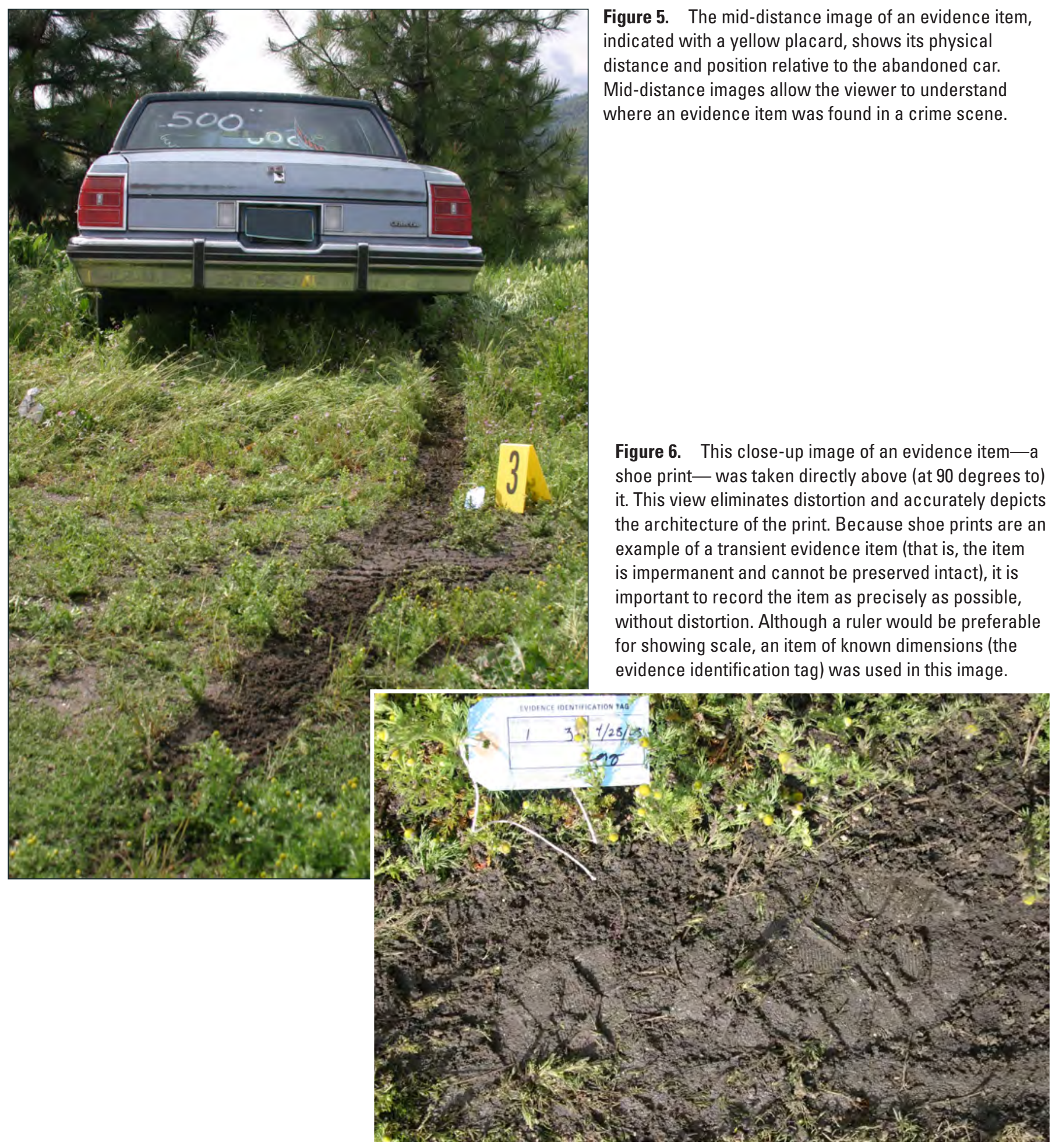

\section{Chain of Custody}

"Chain of custody" refers to the written record (fig. 7) that documents the seizure, custody, control, transfer, and disposition of evidence. The chain begins with the person who originally picked up and packaged the evidence. Each time the evidence item is transferred to another person for analysis or transport, the chain of custody is signed and dated by both the receiving and giving parties. In this way, any question that is posed in a court of law about the location or owner of the evidence at any point in time can be answered. Missing signatures and nonconsecutive dates constitute a break in the chain and may raise questions about whether the evidence was altered or accessed without authorization. Breaks in the chain of custody are serious missteps and may be the difference between a conviction and an acquittal. 


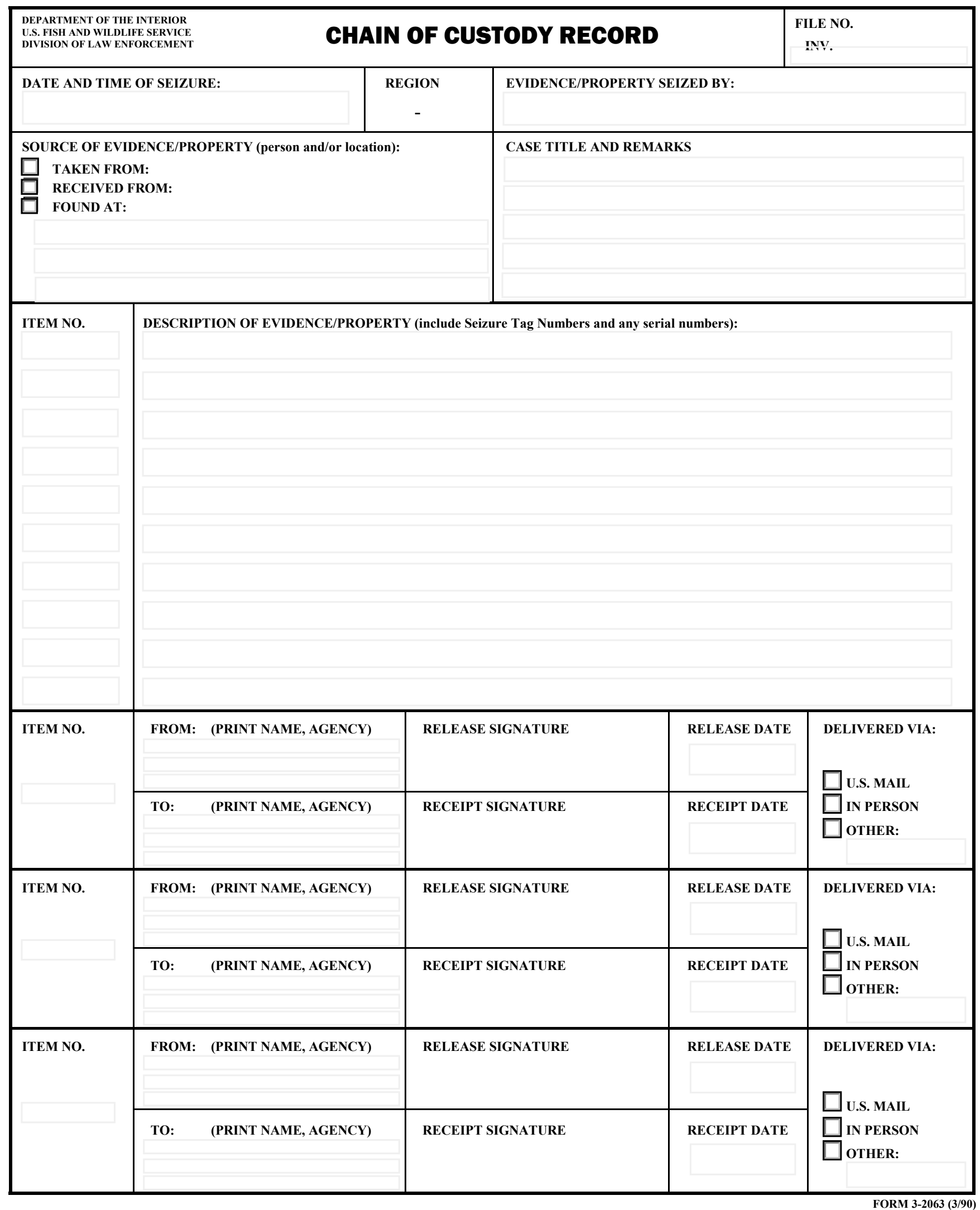

ADDITIONAL TRANSFERS ON REVERSE SIDE

Figure 7. This form is an example of a chain of custody record. Whenever an evidence item is passed between people, each party signs and dates the chain of custody to ensure the integrity of the evidence item. 


\section{Packaging Evidence}

Packaging guidelines for evidence related to Federal crimes is on the National Fish and Wildlife Forensics Laboratory Web site at http://www.lab.fws.gov/pdfs/OM-EU-1000_Evidence_Submission_Guidelines_8-24-12.pdf (accessed October 8, 2014). For specific guidelines on packaging and shipping, contact the laboratory or law enforcement entity that will receive the carcass. Brief, general instructions are outlined here:

1. Carcasses should be placed immediately into a plastic bag and chilled. Direct contact with the animal and the use of ropes should be avoided so as not to inadvertently deposit fibers or other evidence on the surface of the animal.

2. Shell casings and discarded items should be handled with extreme care to avoid smudging possible fingerprints. Lifting and carrying the item by a stick inside the hollow cavity is a useful practice.

3. Impression marks such as tire tracks and boot prints can be lightly covered or cordoned off and protected until a mold can be made to use for identification.

\section{Summary}

Crimes that go undetected may lead to the deaths of more animals. A thorough understanding of the steps taken during the investigation and processing of a crime scene and valuable information provided by the reporting party to the investigating officer, can result in the successful resolution of a case.

\section{References Cited}

Byrd, J.H. and Sutton, L.K., 2011, Defining a crime scene and physical evidence collection, in Huffman, J.E., and Wallace, J.R., eds., Wildlife forensics: Methods and applications: Wiley Publishing, p. 51-64.

Merck, M.D., 2007, Veterinary forensics: Animal cruelty investigations: Blackwell Publishing, p. 21.

\section{Glossary}

autolysis The destruction of tissues or cells of an organism by the action of substances, such as enzymes, that are produced within the organism.

chain of custody The written record or "paper trail" that shows the seizure, custody, control, transfer, and disposition of evidence beginning at its initial creation or retrieval.

deoxyribonucleic acid (DNA) A nucleic acid found mainly in the chromosomes that contain the hereditary information of organisms and some viruses.

evidentiary value The importance of an object or finding to the gathering of data, identification of suspects, and general prosecution of a criminal case; for example, fingerprints on a bullet shell casing may implicate an individual involved in illegal poaching.

reporting party A person who informs a law enforcement agent of a suspected crime. 



\section{Appendix 1. Wildlife Law Enforcement Offices}

Compiled December 20, 2012 


\section{U.S. Fish and Wildlife Service Regional Law Enforcement Offices}

Pacific Region (1): Hawaii, Idaho, Oregon, Washington and the Pacific Trust Territories

911 NE 11th Ave

Portland, OR 97232

Phone: (503) 231-6125 Fax: (503) 231-2193

Southwest Region (2): Arizona, New Mexico, Oklahoma, Texas

P.O. Box 329

Albuquerque, New Mexico 87103

Phone: (505) 248-7889 Fax: (505) 248-7899

Midwest Region (3): Illinois, Indiana, Iowa, Michigan, Minnesota, Missouri, Ohio, Wisconsin

5600 American Blvd, Ste 990

Bloomington, MN 55437-1458

Phone: (612) 713-5320 Fax: (612) 713-5283

Southeast Region (4): Alabama, Arkansas, Florida, Georgia, Kentucky, Louisiana, Mississippi, North Carolina, South Carolina, Tennessee, Puerto Rico, and the U.S. Virgin Islands 1875 Century Blvd, Ste 380

Atlanta, GA 30359

Phone: (404) 679-7057 Fax: (404) 679-7065

Northeast Region (5): Connecticut, Delaware, Maine, Maryland, Massachusetts, New Hampshire, New Jersey, New York, Pennsylvania, Rhode Island, Vermont, Virginia, West Virginia

300 Westgate Center Dr

Hadley, MA 01035

Phone: (413) 253-8274 Fax: (413) 253-8459
Mountain-Prairie Region (6): Colorado, Kansas, Montana, Nebraska, North Dakota, South Dakota, Utah, Wyoming P.O. Box 25486-DFC

Denver, CO 80225

Phone: (303) 236-7540 Fax: (303) 236-7901

Alaska Region (7): Alaska

1011 E Tudor Rd, Mail Stop 151

Anchorage, AK 99503-6199

Phone: (907) 786-3311 Fax: (907) 786-3313

Pacific Southwest (8): California and Nevada

2800 Cottage Way, W-2928

Sacramento, CA 95825

Phone: (916) 414-6660 Fax: (916) 414-6715

National Fish and Wildife Forensics Laboratory: Serving all Regions 1490 E Main St Ashland, OR 97520

Phone: (541) 482-4191 Fax: (541) 482-4989 


\section{State Wildlife Law Enforcement Offices}

The methods for reporting a wildlife crime vary by State, and many States divide law enforcement activity by region. For all 50 State offices listed below, a general phone number is provided for reporting violations. Many States also provide a Webbased form for detailed descriptions of suspected wildlife crime. All effort is made to keep the list below current and accurate, but the user of this manual is strongly encouraged to contact their regional wildlife law enforcement office and record additional contact information, if needed.

\author{
Alabama Wildlife and Freshwater Fisheries Division \\ 21453 Harris Station Rd \\ Tanner, AL 35671 \\ Phone: (256) 353-2634 \\ Operation Game Watch: (800) 272-4263
}

Alaska Department of Fish and Game

Alaska Wildlife Troopers

5700 E Tudor Rd

Anchorage, AK 99507

Phone: (907) 269-5511

\author{
Arizona Game and Fish Department \\ 5000 W Carefree Hwy \\ Phoenix, AZ 85086-5000 \\ Phone: (602) 942-3000 \\ Operation Game Thief: (800) 352-0700 \\ http://www.azgfd.gov/ogt_form.shtml
}

\author{
Arkansas Game and Fish Commission \\ 2 Natural Resources Dr \\ Little Rock, AR 72205 \\ Phone: (800) 364-4263 \\ Stop Poaching Hotline: (800) 482-9262
}

California Department of Fish and Game

1416 Ninth St, Rm 1326

Sacramento, CA 95814

(916) 653-4094

Turn in Poachers: (888) 334-2258 [(888) DFG-CALTIP]

\section{Colorado Parks and Wildlife}

6060 Broadway

Denver, CO 80216

Operation Game Thief

Phone: (877) 262-6448 [(262) COLO-OGT]

Main customer service: (303) 297-1192

Connecticut Department of Energy and

Environmental Protection

$79 \mathrm{Elm} \mathrm{St}$

Hartford, CT 06106-5127

Phone: (860) 424-3000

Turn in Poachers: (800) 842-4357 [(800) 842-HELP]

\author{
Delaware Division of Fish and Wildlife \\ 89 Kings Hwy \\ Dover, DE 19901 \\ Chief Officer phone: 302-739-9913 \\ Operation Game Theft: (800) 292-3030 \\ http://www.dnrec.state.de.us/fw/Mail/Mail1.htm
}

\author{
Florida Fish and Wildlife Conservation Commission \\ South Region A Regional Office \\ 8535 North Lake Blvd \\ West Palm Beach, FL 33412 \\ Phone: (561) 625-5122 \\ Wildlife Alert Program: (888) 404-3922 [(888) 404-FWCC] \\ http://legacy.myfwc.com/wildlifealert/MailMap. \\ asp? region $=\mathrm{CTY}$
}

Georgia Department of Natural Resources

3423 Piedmont Rd, NE, Ste 540

Atlanta, GA 30305

Turn in a Poacher: (800) 241-4113

http://www.georgiawildlife.com/RangerContact

\author{
Hawaii Department of Land and Natural Resources \\ 1151 Punchbowl St, Rm 311 \\ Honolulu, HI 96813 \\ Phone: (808) 587-0077 \\ Turn in Poachers: (855) 356-7847 [(855) DLNR TIP]
}

Idaho Department of Fish and Game

600 S Walnut

Boise, ID 83712

General phone: (208) 334-3700

Report a Poacher: (800) 632-5999

https://fishandgame.idaho.gov/feedback/getForm.

cfm?getForm=3

\author{
Illinois Department of Natural Resources \\ One Natural Resources Way \\ Springfield, IL 62702 \\ Phone: (217) 782-6431 \\ Target Poachers: (877) 236-7529 [(877) 2DNRLAW]
}


Indiana Department of Natural Resources

9822 N Turkey Creek Rd

Syracuse, IN 46567

Phone: (574) 457-8092

Turn in a Poacher: (800) 847-4367 [(800) TIP IDNR]

http://in.gov/dnrtip/webroot/

\section{Iowa Department of Natural Resources}

502 E 9th St

Des Moines, IA 50319

Office number: (515) 281-5918

Turn in Poachers: (800) 532-2020

https://www.iowadnr.gov/tip/index.php/step1

Kansas Department of Wildlife, Parks and Tourism 512 SE 25th Ave

Pratt, KS 67124

General phone: (620) 672-5911

Operation Game Thief: (877) 426-3843

http://kdwpt.state.ks.us/news/Services/Law-Enforcement/

Operation-Game-Thief/Operation-Game-Thief-Report-Form

Kentucky Department of Fish and Wildlife Resources

\#1 Sportsman's Ln

Frankfort, KY 40601

General phone: (800) 858-1549

(800) 252-5378 [(800) 25-ALERT]

Louisiana Department of Wildlife and Fisheries 2000 Quail Dr

Baton Rouge, LA 70898

General phone: (225) 765-2989

Operation Game Thief: (800) 442-2511

Maine Department of Inland Fisheries and Wildlife Gray Regional Headquarters

RR 1, 358 Shaker Rd

Gray, ME 04039

Phone: (207) 657-2345

Operation Game Thief: (800) 253-7887

http://www.maineogt.org/report.php

Maryland Department of Natural Resources

580 Taylor Ave

Annapolis, MD 21401

Phone: (877) 620-8367 [(877) 620-8DNR]

Catch a Poacher: (800) 635-6124

Massachusetts Department of Fish and Game

251 Causeway St, Ste 400

Boston, MA 02114

Phone: (617) 626-1500

Massachusetts Environmental Police: (800) 632-8075

\author{
Michigan Department of Natural Resources \\ P.O. Box 30031 \\ Lansing, MI 48909 \\ Phone: (517) 373-1230 \\ Report all Poaching: (800) 292-7800
}

\author{
Minnesota Department of Natural Resources \\ 500 Lafayette Rd \\ St Paul, MN 55155-4040 \\ Phone: (651) 296-6157 \\ Turn in Poachers: (800) 652-9093 \\ http://www.dnr.state.mn.us/enforcement/tipreporting.html
}

\author{
Mississippi Wildlife, Fisheries, and Parks \\ 1505 Eastover Dr \\ Jackson, MS 39211 \\ General phone: (601) 432-2400 \\ Report a violation: (800) 237-6278 [(800) BE SMART] \\ http://www.mdwfp.com/applications/law\%20enforcement/ \\ default.aspx
}

\author{
Missouri Department of Conservation \\ Conservation Headquarters \\ 2901 W Truman Blvd \\ Jefferson City, MO, 65109 \\ Phone: (573) 751-4115 \\ Operation Game Thief: (800) 392-1111
}

\section{Montana Fish, Wildlife and Parks}

1420 East Sixth Ave

P.O. Box 200701

Helena, MT 59620-0701

Turn in Poachers: (800) 847-6668 [(800) TIP-MONT]

\section{Nebraska Game and Parks Commission}

2200 N 33rd St

Lincoln, NE 68503

Phone: (402) 471-0641

Wildlife Crime Stoppers: (800) 742-7627

Nevada Department of Wildlife

1100 Valley Rd

Reno, NV 89512

General phone: (775) 688-1500

Operation Game Thief: (800) 992-3030

\section{New Hampshire Fish and Game \\ 11 Hazen Dr}

Concord, NH 03301

General law enforcement questions: (603) 271-3127

Operation Game Thief: (800) 344-4262

Violation reporting online at http://www.wildlife.state.nh.us/ OGT/OGT_form.html 
New Jersey Division of Fish and Wildlife

Mail Code 501-03

P.O. Box 420

Trenton, NJ 08625-0420

Operation Game Thief: (855) 648-8478 [(855) OGT-TIPS]

\section{New Mexico Game and Fish}

1 Wildlife Way

Santa Fe, NM 87507

Phone: (505) 476-8000

Operation Game Thief: (800) 432-4263 [(800) 432-GAME]

https://onlinesales.wildlife.state.nm.us/public/ogt

New York Department of Environmental Conservation 625 Broadway

Albany, NY 12233-4500

Phone: (518) 402-8013

Turn in Poachers: (800) 847-7332 [(800) TIPP DEC]

http://www.dec.ny.gov/regulations/67751.html

\section{North Carolina Wildlife Resources Commission}

Division of Law Enforcement

1717 Mail Service Center

Raleigh, NC 27699-1717

Phone: (919) 707-0030

Report wildlife violations: (800) 662-7137

\section{North Dakota Game and Fish Department}

100 N Bismarck Expy

Bismarck, ND 58501-5095

Phone: (701) 328-6300

Report all poachers: (800) 472-2121

\section{Ohio Division of Wildlife}

TIP Headquarters, Division of Wildlife

2045 Morse Rd, Bldg G

Columbus, OH 43229-6693

Turn in a Poacher (TIP): (800) 762-2437

[(800) 762-POACHER]

http://www.dnr.state.oh.us/Home/wild_resourcessubhomepage/TurnInaPoacher/tabid/17888/Default.aspx

Oklahoma Department of Wildlife Conservation

1801 N Lincoln

Oklahoma City, OK 73105

Phone: (405) 521-3719

Operation Game Thief: (800) 522-8039

\section{Oregon Fish and Wildlife Division}

Public Service Building

255 Capitol St NE, 4th Fl

Salem, OR 97310

General phone: (503) 378-3720

Turn in Poachers (TIP) Hotline: (800) 452-7888

http://www.oregon.gov/osp/FW/docs/suspicious_activity_ form_fillable.pdf
Pennsylvania Game Commission

2001 Elmerton Ave

Harrisburg, PA 17110-9797

Phone: (717) 787-4250

Turn in a Poacher: (888) 742-8001

http://www.portal.state.pa.us/portal/server.

pt?open $=514 \&$ objID $=614775 \&$ mode $=2$

Rhode Island Department of Environmental Management 235 Promenade St

Providence, RI 02908-5767

General phone: (401) 222-6800

24-hour hotline: (401) 222-3070

\section{South Carolina Department of Natural Resources}

1000 Assembly St

Columbia, SC 29201

Law Enforcement phone: (803) 734-4002

Report violations: (800) 922-5431

\section{South Dakota Game, Fish and Parks}

523 East Capitol Ave

Pierre, SD 57501

Phone: (605) 773-4243

Turn in Poachers: (888) 683-7224 [(800) OVERBAG]

https://www.state.sd.us/eforms/secure/eforms/E2098V1-AnonymousTIP.pdf

Tennessee Wildlife Resources Agency

440 Hogan Rd

Nashville, TN 37220

General phone: (615) 781-6500

Report a violation: (800) 831-1174

Texas Parks and Wildlife

4200 Smith School Rd

Austin, TX 78744

Phone: (512) 389-4848

Operation Game Thief: (800) 792-4263

Utah Division of Wildlife Resources

1594 W North Temple, Ste 2110

Box 146301

Salt Lake City, UT 84114-6301

General phone: (801) 538-4700

Turn in a Poacher: (800) 662-3337

http://roverfish.com/dwr/index.php?option=com_breezingform $\mathrm{s} \&$ view $=$ form\&Itemid $=56$

\section{Vermont Fish and Wildlife Department}

103 South Main St

Waterbury, VT 05671-0501

General phone: (802) 241-3700

Operation Game Thief: (800) 752-5378 [(800) 75 ALERT]

http://www.vtfishandwildlife.com/laws_thief.cfm 
Virginia Department of Game and Inland Fisheries 4010 West Broad St

Richmond, VA 23230

General phone: (804) 367-1000

Wildlife Crime Line: (800) 237-5712

\section{Washington Department of Fish and Wildlife}

Natural Resources Building

1111 Washington St SE

Olympia, WA 98501

Main office: (360) 902-2200

Turn in a Poacher (TIP): (877) 933-9847

http://wdfw.wa.gov/enforcement/violation/index.php

\section{West Virginia Division of Natural Resources}

Building 74

324 Fourth Ave

South Charleston, WV 25303

Phone: (304) 558-2784

http://www.wvdnr.gov/LEnforce/Poachers.shtm
Wisconsin Department of Natural Resources

$101 \mathrm{~S}$ Webster St

PO Box 7921

Madison, WI 53707-7921

Phone: (608) 266-2621

Report a violation: (800) 847-9367

\section{Wyoming Game Wardens Association}

Wyoming Wildlife Protectors Assoc.

3030 Energy Ln

Casper, WY 82604

Wyoming Game and Fish: (307) 777-4600

Stop Poaching Program: (877) 943-3847 [(877) WGFD TIP]

http://gf.state.wy.us/wildlife/enforcement/stoppoaching/

submitTip.aspx 

